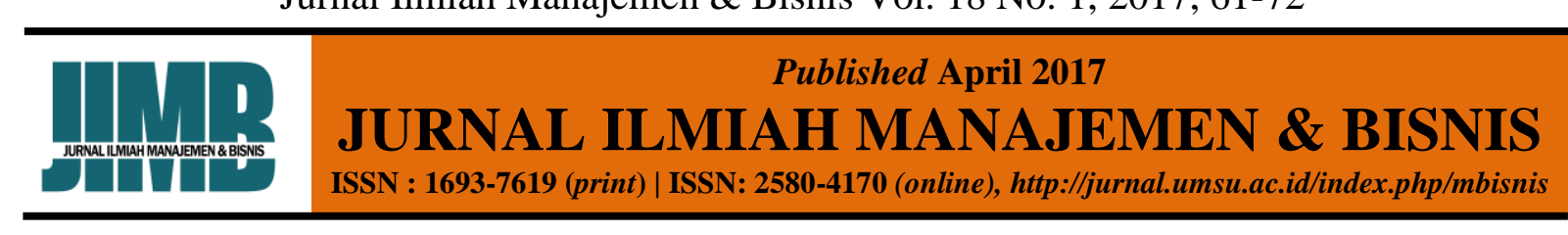

\title{
Pengaruh Promosi, Harga Dan Kualitas Pelayanan Terhadap Kepuasan Konsumen Pada Titipan Kilat JNE Medan
}

\author{
Bagus Handoko \\ Prodi Manajemen, STIE Harapan Medan, Indonesia \\ Email: baguscipta@gmail.com
}

\begin{abstract}
ABSTRAK
Tujuan penelitian ini adalah untuk mengetahui apakah terdapat pengaruh Promosi, Harga dan Kualitas Pelayanan terhadap Kepuasan Konsumen di PT. Maxim Housewares Indonesia Medan. Hasil penelitian ini adalah terdapat pengaruh yang signifikan Promosi terhadap Kepuasan Konsumen, Besarnya pengaruh Promosi Terhadap Kepuasan Konsumen adalah 20,9\% Terdapat pengaruh yang signifikan Harga terhadap Kepuasan konsumen, besarnya pengaruh Harga terhadap Kepuasan konsumen adalah sebesar 16,2\% Terdapat pengaruh yang signifikan Kualitas pelayanan terhadap Kepuasan konsumen, besarnya pengaruh Kualitas pelayanan terhadap Kepuasan konsumen adalah sebesar $63,6 \%$ Promosi, Harga dan Kualitas pelayanan secara bersama- sama berpengaruh signifikan terhadap Kepuasan konsumen di PT. Maxim Houseware Indonesia Medan, dengan tingkat kemampuan Promosi, Harga dan Kualitas pelayanan untuk menjelaskan Kepuasan konsumen adalah sebesar 82,5\% sedangkan sisanya sebesar $17,5 \%$ dijelaskan oleh variabel lain yang tidak dimasukkan ke dalam model penelitian ini.
\end{abstract}

Kata Kunci: Promosi, Harga, Kualitas Pelayanan, Kepuasan

\section{The Influence of Promotion, Price, and Quality of Service to Costumer Satisfaction at JNE Company Medan}

\begin{abstract}
The purpose of this study is to determine whether there is influence Promotion, Price and Quality Service to Customer Satisfaction at PT. Maxim Housewares Indonesia Medan. The result of this research is there is significant influence of Promotion to Consumer Satisfaction, The amount of influence of Promotion on Consumer Satisfaction is 20,9\% There is significant influence of Price to Customer Satisfaction, the amount of influence Price to Customer Satisfaction is equal to $16,2 \%$ There is significant influence Quality service to consumer satisfaction, the amount of influence Quality of service to Customer Satisfaction is equal to 63.6\% Promotion, Price and Quality of service together significant effect on Consumer Satisfaction at PT. Maxim Houseware Indonesia Medan, with the capability of Promotion, Price, and Quality of service to explain customer satisfaction is equal to $82,5 \%$ while the rest equal to $17,5 \%$ explained by another variable not included in this research model.
\end{abstract}

Keywords: Promotion, Price, Service Quality, Satisfaction

How to cite:

Handoko, B. (2017). Pengaruh Promosi, Harga Dan Kualitas Pelayanan Terhadap Kepuasan Konsumen Pada Titipan Kilat JNE Medan. Jurnal Ilmiah Manajemen \& Bisnis, 18(1), 61-72. 


\section{PENDAHULUAN}

Pemasaran yang baik dapat terlihat dari adanya saling ketergantungan antara konsumen dengan produsen, sedang pemasaran yang tidak baik terlihat dari tidak adanya ketergantungan antara kedua belah pihak tersebut. Untuk dapat berhasil dalam melakukan proses pemasaran, langkah yang harus diambil adalah mengenali konsumen anda dahulu, berilah apa yang mereka inginkan, gunakan media yang tepat sesuai dengan sasaran, gunakan non media dan capailah konsumen. Hal - hal tersebut dilakukan agar kepuasan konsumen tercapai. Kepuasan adalah situasi kognitif pembeli berkenaan dengan kesepadanan antara hasil yang didapatkan dibandingkan dengan pengorbanan yang dilakukan (Howard \& Shelt dalam Tjiptono, $2005: 349$ ).

Berkembangnya jumlah perusahaan titipan kilat di Indonoesia menjadikan Konsumen yang kurang puas terhadap produk yang diberikan oleh perusahaan dapat disebab oleh banyak hal. Bisa karena purna jual yang kurang baik, atau sangat sulit mendapatkan pelayanan purna jual. Bisa juga kurang puasnya konsumen terhadap produk perusahaan karena harga yang ditawarkan kurang sesuai dengan kualitas produk. Kemudian bisa juga disebabkan oleh informasi yang didapat oleh konsumen sangat kurang, sehingga ketika menggunakan produk tidak sesuai dengan informasi yang didapat, menimbulkan rasa kurang puas di dalam diri konsumen. Informasi ini bisa didapat melalui promosi promosi yang dilakukan oleh perusahaan.

Faktor - faktor yang dapat mempengaruhi kepuasan pelanggan dalam penelitian ini, diprediksi adalah promosi, harga yang ditawarkan oleh PT Maxim Houseware Indonesia Medan itu sendiri dan kualitas pelayanan yang diberikan oleh karyawan perusahaan.

\section{KAJIAN TEORI \\ Promosi}

Promosi merupakan salah satu bagian dari rangkaian kegiatan pemasaran suatu produk barang ataupun jasa. Promosi adalah suatu bidang kegiatan marketing dan merupakan komunikasi yang dilaksanakan perusahaan kepada pembeli atau konsumen yang memuat pemberitaan (information), membujuk (persuasion) dan mempengaruhi (influence). Segala kegiatan itu bertujuan untuk meningkatkan penjualan, betapapun berkualitasnya suatu produk, bila konsumen belum pernah mendengarnya dan tidak yakin bahwa produk atau barang itu akan berguna bagi mereka, maka mereka tidak akan pernah membelinya (Kotler, 2000: 219).

Menurut Hair dan Daniel (2001:145) "Promosi adalah komunikasi dari para pemasar yang menginformasikan, membujuk dan mengingatkan para calon pembeli suatu produk dalam rangka mempengaruhi pendapat mereka atau memperoleh suatu respon".

Terdapat 4 jenis promosi yang biasa dilakukan oleh dalam kegiatan pemasaran yaitu : iklan, promosi penjualan, penjualan personal (Personal Selling) dan publisitas (Swastha dan Sukotjo, 2000:124). Keempat jenis promosi ini bersama-sama menjadi bagian dari sebuah bauran promosi yang ingin dikelola secara strategis oleh para pemasar untuk dapat mencapai tujuan organisasi.

\section{Iklan}

Iklan (advertising) merupakan penyajian informasi non personal tentang suatu produk, merk, perusahaan atau took yang dilakukan dengan bayaran tertentu. Pada iklan biasanya ditampakkan organisasi yang mensponsorinya. Iklan ditujukan untuk mempengaruhi afeksi dan kognisi konsumen-evaluasi, perasaan pengetahuan, makna kepercayaan, sikap dan citra yang berkaitan dengan produk dan merek. Dalam 
prakteknya, iklan telah dianggap sebagai manajemen citra (image management) menciptakan dan memelihara citra dan makna dalam benak konsumen. Walaupun pertama-tama iklan akan mempengaruhi afeksi dan kognisi, tujuannya yang paling akhir adalah bagaimana mempengaruhi perilaku pembelian konsumen.

1. Promosi Penjualan

Promosi penjualan adalah bentuk persuasi langsung melalui penggunaan berbagai insentif yang dapat diatur untuk merangsang pembelian produk dengan segera dan atau meningkatkan jumlah barang yang dibeli oleh pelanggan. Tujuan dari promosi penjualan, perusahaan dapat menarik pelanggan baru, mempengaruhi pelanggannya untuk mencoba produk baru, mendorong pelanggan membeli lebih banyak, menyerang aktivitas promosi pesaing, meningkatkan impulse buying (pembelian tanpa rencana sebelumnya), atau mengupayakan kerja sama yang lebih erat dengan pengecer

2. Penjualan Personal

Penjualan personal (Personal selling) adalah komunikasi langsung (tatap muka) antara penjual dan calon pelanggan untuk memperkenalkan suatu produk kepada calon pelanggan dan membentuk pemahaman pelanggan terhadap produk sehingga mereka kemudian akan mencoba dan membelinya

\section{Publisitas}

Publisitas (publicity) adalah bentuk-bentuk komunikasi tentang perusahaan, produk, atau mereka si pemasar yang tidak membutuhkan pembayaran misalnya, sebuah artikel di majalah PC World yang membandingkan berbagai macam merek perangkat lunak pengolah data merupakan informasi produk yang sangat berguna bagi konsumen namun tidak dibebankan biaya sama sekali pada para pemasar perangkat lunak tersebut. Demikian pula halnya dengan penjabatan produk atau merek baru, perbandi ngan merek di jurnal dagang, surat kabar atau majalah berita, atau diskusi radio dan talk show di televisi semuanya menyajikan berbagai informasi produk baru bagi konsumen

\section{Harga}

Harga menurut Kotler (2001:124) adalah sejumlah uang yang ditukarkan untuk sebuah produk atau jasa. Lebih jauh lagi, harga adalah sejumlah nilai yang konsumen tukarkan untuk jumlah manfaat dengan memiliki atau menggunakan suatu barang atau jasa. Harga merupakan hal yang diperhatikan konsumen saat melakukan pembelian. Sebagian konsumen bahkan mengidentifikasikan harga dengan nilai. Menurut Swasta (2001:89), harga merupakan sejumlah uang (ditambah beberapa barang kalau mungkin) yang dibutuhkan untuk mendapatkan sejumlah kombinasi dari barang beserta pelayanannya.

Harga seringkali digunakan sebagai indikator nilai bilamana harga tersebut dihubungkan dengan manfaat yang dirasakan atas suatu barang atau jasa. Dengan demikian dapat disimpulkan bahwa pada tingkat harga tertentu, bila manfaat yang dirasakan konsumen meningkat, maka nilainya akan meningkat pula (Tjiptono, 2005:97). Dalam penentuan nilai suatu barang atau jasa, konsumen membandingkan kemampuan suatu barang atau jasa dalam memenuhi kebutuhannya dengan kemampuan barang atau jasa subtitusi.

Harga merupakan salah satu atribut penting yang dievaluasi oleh konsumen sehingga manajer perusahaan perlu benarbenar memahami peran tersebut dalam mempengaruhi sikap konsumen. Harga sebagai atribut dapatdiartikan bahwa harga merupakan konsep keanekaragaman yang 
memiliki arti berbeda bagi tiap konsumen, tergantung karakteristik konsumen, situasi dan produk (John C. Mowen dan Michael Minor, 2002:132). Dengan kata lain, pada tingkat harga tertentu yang telah dikeluarkan, konsumen dapat merasakan manfaat dari produk yang telah dibelinya. Dan konsumen akan merasa puas apabila manfaat yang mereka dapatkan sebanding atau bahkan lebih tinggi dari nominal uang yang mereka keluarkan.

\section{Kualitas Pelayanan}

Untuk mengetahui dasar dan apa itu pelayanan, maka perlu dipahami definisi dari pelayanan yang telah dikemukakan. Menurut Yoeti (2001:1) Pelayanan adalah suatu produk yang tidak nyata (intangible) dari hasil kegiatan timbal balik antara pemberi jasa (producer) dan penerima jasa (customer) melalui suatu atau beberapa aktivitas untuk memenuhi kebutuhan pelanggan.

Menelusuri arti pelayanan tidak lepas dari masalah kepentingan umum, yang menjadi asal usul timbulnya istilah pelayanan publik. Dengan kata lain antara kepentingan umum ada kaitannya dengan pelayanan umum. Pelayanan menurut Payne (2000:49), merupakan hal, cara atau melayani, menyediakan segala apa yang diperlukan orang. Sedangkan menurut Fitzsimmons (2001:51), Pelayanan adalah suatu usaha yang bertujuan untuk memuaskan individu dengan memenuhi kebutuhan (needs) ataupun keinginan (wants) individu tersebut.

Dalam dunia bisnis dengan persaingan banyak perusahaan yang memberikan produk dan kualitas yang saling bersaing. Dalam situasi yang seperti ini, maka yang paling menentukan adalah organisasi yang dapat menghasilkan pelayanan yang terbaik. Memuaskan pengguna jasa sebenarnya adalah memenuhi kebutuhan-kebutuhan mereka sebagai pembeli pelayanan maka dihadapkan pada tantangan untuk dapat memenuhi kebutuhan pengguna jasa.

Menurut Payne (2000 : 17), pelayanan yang diberikan kepada pengguna jasa sangat penting bagi perusahaan yang menghasilkan jasa karena :

a. Pengguna jasa merupakan sumber pendapatan perusahaan karena pengguna jasa membayar jasa yang dijual.

b. Kompensasi yang semakin hebat pada saat ini seiring dengan kemajuan teknologi.

c. Hubungan erat antara jasa dengan pengguna jasa karena jasa dan pengguna jasa merupakan suatu bagian yang tidak dapat dipisahkan.

d. Masyarakat semakin kritis, semakin maju dan semakin mengetahui hak-hak untuk dilayani dengan sebaik-baiknya.

e. Pelayanan merupakan produk kerjasama ketertiban satu unit kerja dengan unit kerja lainnya yang memerlukan perilaku dan sikap kerjasama dari para petugas.

Menurut Yoeti (2001 : 78), Dalam salah satu studi mengenai kualitas pelayanan yang melibatkan 800 (delapan ratus) pengguna jasa berusia 25 tahun ke atas disimpulkan bahwa terdapat lima dimensi kualitas pelayanan sebagai berikut :

a. Tangibles atau bukti fisik adalah kemampuan suatu perusahaan dalam menunjukkan eksistensinya kepada pihak eksternal. Penampilan dan kemampuan sarana dan prasarana fisik perubahan dari keadaan lingkungan sekitar merupakan bukti nyata dari pelayanan yang diberikan oleh pemberi jasa yang meliputi fasilitas fisik (gedung, gudang dan sebagainya), perlengkapan dan peralatan yang digunakan (teknologi) serta penampilan karyawan.

b. Reability atau andalan adalah kemampuan suatu perusahaan untuk memberikan pelayanan sesuai yang dijanjikan secara akurat dan terpercaya. Kinerja harus sesuai dengan harapan pengguna jasa yang berarti ketepatan 
waktu, pelayanan yang sama untuk semua pengguna jasa tanpa kesalahan, sikap yang simpatik dan akurasi yang tinggi.

c. Responsiveness atau ketanggapan adalah suatu kemauan untuk membantu dan memberikan pelayanan yang cepat / responsif dan tepat kepada pengguna jasa dengan penyampaian informasi yang jelas. Tidak membiarkan pengguna jasa menunggu tanpa adanya suatu alasan yang jelas menyebabkan persepsi yang negatif dalam kualitas pelayanan.

d. Assurance atau jaminan dan kepastian adalah pengetahuan, sopan santun dan kemampuan para karyawan perusahaan untuk menumbuhkan rasa percaya pengguna jasa kepada perusahaan yang terdiri dari beberapa komponen antara lain komunikasi, kredibilitas, keamanan, kompetensi dan sopan santun.

e. Empathy adalah memberikan perhatian yang tulus dan bersifat individual atau pribadi yang diberikan kepada pengguna jasa dengan berupaya memahami keinginan mereka. Suatu perusahaan diharapkan memiliki pengertian dan pengetahuan secara spesifik serta memiliki waktu pengoperasian yang nyaman bagi pengguna jasa.

\section{Kepuasan Konsumen}

Menurut Kotler (2001:56) kepuasan konsumen adalah perasaan senang atau kecewa seseorang yang berasal dari perbandingan antara kesannya terhadap kinerja atau hasil suatu produk dengan harapan-harapannya. Jika kenyataan lebih dari yang diharapkan, maka layanan dapat dikatakan bermutu sedangkan jika kenyataan kurang dari yang diharapkan, maka layanan dikatakan tidak bermutu. Apabila kenyataan sama dengan harapan, maka layanan dise but memuaskan. Dengan demikian service quality dapat didefinisikan sebagai jauhnya perbedaan antara kenyataan dan harapan konsumen atas layanan yang mereka terima (Lupiyoadi, 2001).

Engel, et al dalam Tjiptono, (2005:89) menyatakan bahwa kepuasan pelanggan merupakan evaluasi purna beli dimana alternatif yang dipilih sekurang-kurangnya sama atau melampaui harapan pelanggan, sedangkan ketidakpuasan timbul apabila hasil (outcome) tidak memenuhi harapan. Bila kepuasan konsumen terhadap barang/jasa jauh dibawah apa yang diharapkan, maka konsumen akan kehilangan minat terhadap produsen/penyedia jasa dalam hal ini adalah rumah sakit. Demikian pula sebaliknya, jika barang/jasa yang mereka nikmati memenuhi/melebihi tingkat kepentingannya, maka konsumen akan cenderung memakai lagi barang/jasa tersebut (Kotler, 2001:59).

Kepuasan pasien adalah suatu tingkat perasaan pasien yang timbul sebagai akibat dari kinerja layanan kesehatan yang diperolehnya setelah pasien membandingkannya dengan apa yang diharapkannya. Pasien baru akan merasa puas apabila kinerja layanan kesehatan yang diperolehnya sama atau melebihi harapannya dan sebaliknya, ketidakpuasan atau perasaan kecewa pasien akan muncul apabila kinerja layanan kesehatan yang diperolehnya itu tidak sesuai dengan harapannya. Dengan demikian, kepuasan memang menjadi variabel yang sangat penting untuk mengukur pemasaran pelayanan kesehatan yang berkaitan dengan hasil akhir dari pelayanan yang telah diberikan apaakah sesuai dengan harapan atau keinginan pasien.

Menurut Lupiyoadi (2001:158) menyatakan bahwa dalam menentukan kepuasan, terdapat lima faktor utama yang harus diperhatikan oleh perusahaan, yaitu:

a. Kualitas produk; Pelanggan akan merasa puas bila hasil evaluasi mereka menunjukkan bahwa produk yang mereka gunakan berkualitas. 
b. Kualitas pelayanan; Terutama untuk industri jasa, pelanggan akan merasa puas bila mereka mendapatkan pelayanan yang baik atau yang sesuai dengan yang diharapkan.

c. Emosional; Pelanggan akan merasa bangga dan mendapatkan keyakinan bahwa orang lain akan kagum terhadap dia bila menggunakan produk dengan merek tertentu yang cenderung mempunyai tingkat kepuasan lebih tinggi. Kepuasan yang diperoleh bukan karena kualitas dari produk tetapi nilai social atau self esteem yang membuat pelanggan menjadi puas terhadap merek tertentu.

d. Harga; Produk yang mempunyai kualitas sama tetapi menetapkan harga yang relatif murah akan memberikan nilai yang lebih tinggi kepada pelanggannya.

e. Biaya; Pelanggan tidak perlu mengeluarkan biaya tambahan atau tidak perlu membuang waktu untuk mendapatkan suatu produk atau jasa cenderung puas terhadap produk atau jasa itu.

Perusahaan jasa harus dapat mengetengahkan secara konsisten jasa yang berkualitas lebih tinggi daripada para pesaingnya. Pelanggan (konsumen) memilih penyedia jasa dengan membandingkan pelayanan yang dirasakan (perceived services) dengan yang diharapkan (expected services). Jika pelayanan yang dirasakan berada dibawah yang diharapkan, maka timbul suatu ketidak puasaan pelanggan, rasa kepercayaan pelanggan terhadap penyedia jasa menjadi berkurang (hilang), pendapatan perusahaan menurun dan akhirnya membahayakan kelangsungan hidup usahanya. Sebaliknya jika pelayanan yang dirasakan sama atau lebih besar dari yang diharapkan, maka pelanggan merasa puas. Mereka akan menggunakan kembali jasa tersebut dan memberitahukan kepada yang lain, sehingga menjadi alat promosi yang efektif, dan kelangsungan hidup perusahaan menjadi lebih terjamin. Oleh karena itu penyedia jasa harus dapat mengidentifikasikan keinginan konsumen dalam hal kualitas pelayanan secara umum maupun khusus.

\section{Hipotesis}

Berdasarkan pada kerangka konseptual, maka penulis menetapkan hipotesis pada penelitian ini adalah terdapat pengaruh Promosi terhadap Kepuasan Konsumen pada PT Maxim Houseware Indonesia Medan, terdapat pengaruh Harga terhadap Kepuasan Konsumen pada PT Maxim Houseware Indonesia Medan, terdapat pengaruh Kualitas Pelayanan terhadap Kepuasan Konsumen pada PT Maxim Houseware Indonesia Medan, terdapat pengaruh Promosi, Harga dan Kualitas Pelayanan terhadap Kepuasan Konsumen pada PT Maxim Houseware Indonesia Medan.

\section{Kerangka Berpikir}

Berdasarkan pada penjelasan penjelasan diatas, seperti pada latar belakang masalah dan rumusan masalah, maka penulis menyusun kerangka konseptual pada penelitian ini adalah sebagai berikut:

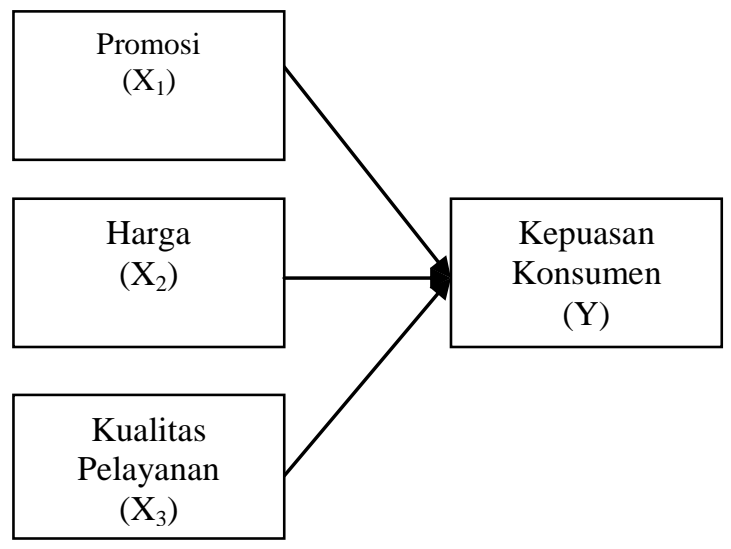

Gambar 1. Kerangka Konseptual

\section{METODE}

Populasi adalah sekumpulan satuan analisis yang didalamnya terkandung 
informasi yang ingin diketahui. Target populasi adalah sekumpulan satuan pengamatan atau objek yang memiliki informasi yang dibutuhkan peneliti. Adapun yang menjadi populasi dalam penelitian ini adalah seluruh konsumen yang berkunjung di PT Maxim Houseware Indonesia Medan. Sampel adalah jumlah yang mewakili dari populasi yang akan dijadikan sebagai responden penelitian Jalaluddin (2002:83). Teknik pengambilan sampling yang digunakan adalah metode Purposive Sampling. Metode Purposive Sampling merupakan metode pengambilan sampel menggunakan kriteria tertentu yang berdasarkan justifikasi peneliti. Adapun yang menjadi kriteria pengambilan sampel penelitian ini adalah konsumen PT. Maxim Housewares Indonesia Gatot Subroto Medan yang berkunjung pada outlet perusahaan, periode Pengamatan dan pengambilan sampel untuk ukuran 3 bulan, yaitu Mei Juli 2016, sampel merupakan konsumen berusia $>21$ tahun

Dalam mengumpulkan data penulis menggunakan beberapa metode pengumpulan data berupa angket (kuesioner) yaitu membuat pertanyaan atau kuesioner yang akan dibagikan kepada responden menggunakan Skala Likert.

Uji validitas adalah untuk mengukur ketepatan suatu instrumen penelitian atau dengan kata lain bahwa uji ini dilakukan untuk mengetahui sejauhmana item pertanyaan yang digunakan dapat menguji suatu model dalam penelitian ini. Adapun kriteria pengujian ini dilakukan dengan membandingkan nilai korelasi masingmasing item pertanyaan terhadap totalnya ( r- hitung ) dengan r-tabel, dimana item pertanyaan dikatakan valid jika r-hitung lebih besar dari r-tabel ( $r$-hitung > r-tabel ). Uji reliabilitas dilakukan untuk menjamin instrumen yang digunakan merupakan sebuah instrumen handal, konsisten, stabil dan dependibalitas, sehingga apabila digunakan berulang-ulang maka akan menghasilkan yang sama. Reliabilitas yang tinggi ditunjukkan dengan nilai 1 , reliabilitas dianggap sudah cukup memuaskan atau tinggi adalah lebih besar atau sama dengan 0,60 . Untuk pengujian ini dilakukan dengan teknik Cronbach Alfa.

Teknik Analisa data yang digunakan adalah model Model analisis regresi berganda (Sugiyono, 2006:254) dengan model persamaan regesi sebagai berikut:

$Y=a+b_{1} X_{1}+b_{2} X_{2}+b_{3} X_{3}+e$

Dimana: Y: Kepuasan Konsumen, a: Konstanta, $b_{1}$ : Koefisien regresi variabel $X_{1}, b_{2}$ Koefisien regresi variabel $X_{2}, b_{3}$ : Koefisien regresi variabel $\mathrm{X}_{3}, \mathrm{X}_{1}$ : Promosi, $\mathrm{X}_{2}$ : Harga, $\mathrm{X}_{3}$ : Kualitas Pelayanan

Untuk melihat pengaruh variabel bebas terhadap variabel terikat, masingmasing dilakukan pengujian hipotesis adalah Uji Parsial ( Uji t ) dilakukan untuk mengetahui pengaruh masing-masing variabel bebas terhadap variabel terikat. Kriteria pengujian dilakukan dengan membandingkan nilai t-hitung dengan $\mathrm{t}$ tabel yaitu :

1) Jika t-hitung > t-tabel, tolak $\mathrm{H}_{o}$ terima $\mathrm{H}_{a}$ pada taraf signifikan $95 \%$

2) Jika t-hitung < t-tabel, terima $\mathrm{H}_{\mathrm{o}}$ tolak $\mathrm{H}_{\mathrm{a}}$ pada taraf signifikan $95 \%$

Uji Simultan ( Uji F ), dilakukan untuk mengetahui pengaruh variabel bebas terhadap variabel terikat secara serempak (simultan). Adapun kriteria pengujian dilakukan dengan membandingkan F-hitung dengan F-tabel, sebagai berikut:

1) Bila $F_{\text {hitung }} \geq F_{\text {tabel }}$ pada taraf signifikan 95\%, maka hipotesis alternatif diterima.

2) Bila $F_{\text {hitung }} \geq F_{\text {tabel }}$ pada taraf signifikan 95\%, maka hipotesis alternatif ditolak.

Uji ini dilakukan untuk mengetahui seberapa besar persentase variabel Promosi, Harga dan Kualitas Pelayanan mampu menerangkan variabel Kepuasan Konsumen. Uji ini dapat dilihat dengan menggunakan rumus $\mathrm{D}=\mathrm{R}^{2} \times 100 \%$. 


\section{HASIL DAN PEMBAHASAN \\ Hasil Penelitian}

Hasil uji validitas menggunakan SPSS menunjukkan seluruh instrument penelitian pada setiap variabel telah memenuhi syarat validitas, yaitu $r_{\text {hitung }}>r_{\text {tabel }}(0,259)$. Oleh sebab itu, indikator - indikator tersebut dapat digunakan untuk mengukur variabel penelitian ini. Sedangkan uji reliabilitas ini menggunakan SPSS diperoleh hasil nilai Cronbach Alfa Hitung untuk variabel Promosi sebesar 0,652, variabel Harga sebesar 0.696, variabel Kualitas Pelayanan sebesar 0.666 dan variabel kepuasan konsumen sebesar 0.671 , nilai reliabilitas ini menunjukkan bahwa seluruh variabel telah memenuhi syarat uji reliabilitas, dimana nilai Cronbach Alfa hitung lebih besar dari nilai Cronbach Alfa standar yaitu nilai reliabilitas yang tinggi ditunjukkan dengan nilai 1, reliabilitas dianggap sudah cukup memuaskan atau tinggi adalah lebih besar atau sama dengan 0,60.

Uji Normalitas ini digunakan untuk melihat tingkat kenormalan data yang akan digunakan dan dimasukkan ke dalam model penelitian. Hasil uji normalitas dengan menggunakan Kolmogorov Smirnov dapat dilihat seperti pada tabel berikut ini:

Tabel 1. Uji Normalitas

One-Sample Kolmogorov-Smirnov Test

\begin{tabular}{|ll|r|}
\hline & & Unstandardized Residual \\
\hline Normal Parameters & & 60 \\
& & .0000000 \\
Most Extreme Differences & Mean & Std. Deviation \\
& Absolute & 1.29417946 \\
& Positive & .063 \\
& Negative & .044 \\
Kolmogorov-Smirnov Z & & -.063 \\
Asymp. Sig. (2-tailed) & .486 \\
\multicolumn{2}{c|}{ a. Test distribution is Normal. } & .972 \\
\hline
\end{tabular}

Tabel 1 menunjukkan bahwa nilai Asymp. Sig adalah sebesar 0.972 lebih besar dari 0,05 , sehingga disimpulkan bahwa data telah terdistribusi secara normal.

\section{Uji Multikolinearitas}

Uji ini dilakukan untuk melihat dan menyakinkan bahwa variabel - variabel bebas dalam penelitian ini terbebas dari saling mempengaruhi. Uji ini dinyatakan terkena multikolinearitas atau tidak dilihat dari nilai Tolerance yang ada pada kolom Collinearity Statistic menunjukkan nilainya lebih kecil dari 1, atau dapat juga dilihat dari nilai VIF yang bernilai harus lebih kecil dari 5 (Suliyanto, 2011). Untuk mengetahui uji ini dapat dilihat pada tabel berikut ini:

Tabel 2. Uji Multikolinearitas

\begin{tabular}{|ll|r|r|}
\hline \multirow{2}{*}{ Model } & & \multicolumn{2}{|c|}{ Collinearity Statistics } \\
\cline { 3 - 4 } & & Tolerance & \multicolumn{1}{c|}{ VIF } \\
\hline 1 & (Constant) & & \\
& Promosi & .353 & 2.834 \\
& Harga & .493 & 2.030 \\
& Kualitas Pelayanan & .289 & 3.460 \\
\hline
\end{tabular}




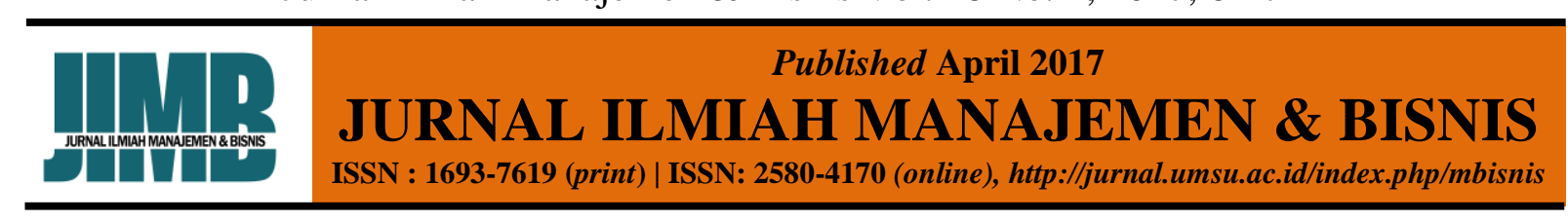

Jika dilihat pada tabel 2 diketahui bahwa variabel Promosi $\left(\mathrm{X}_{1}\right)$, Harga $\left(\mathrm{X}_{2}\right)$, dan Kualitas Pelayanan $\left(\mathrm{X}_{3}\right)$ telah terbebas dari multikolinearitas dimana masing masing nilai Tolerance lebih kecil dari 5.

\section{Uji Heteroskedastisitas}

Uji heteroskedastisitas bertujuan untuk melihat apakah di dalam model regresi terjadi ketidaksamaan variabel dari residual satu pengamatan ke pengamatan yang lain. Pada uji ini digunakan metode Scatterplot yang dapat dilihat pada gambar berikut ini:

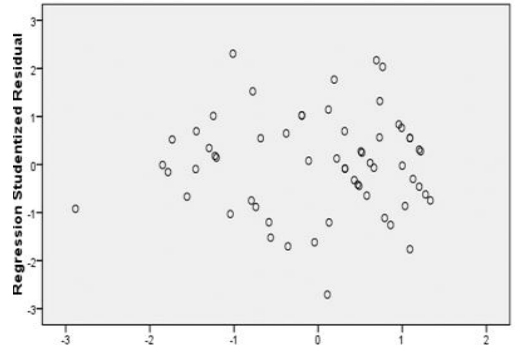

Gambar 2. Uji Heteroskedastisitas

\section{Regresi Linear Berganda}

Berdasarkan olahan data yang telah dilakukan, maka dapat diketahui bahwa model hubungan dari analisis regresi linear berganda ini dilihat dari tabel berikut ini:

Tabel 3. Analisis Regresi Linear Berganda

\begin{tabular}{|cl|r|r|r|}
\hline \multirow{2}{*}{ Model } & & \multicolumn{2}{c|}{} & \multicolumn{2}{c|}{$\begin{array}{c}\text { Standardized } \\
\text { Coefficients }\end{array}$} \\
\cline { 3 - 5 } & & B & \multicolumn{1}{c|}{ Std. Error } & \multicolumn{1}{c|}{ Beta } \\
\hline \multirow{2}{*}{1} & (Constant) & 2.380 & 1.425 & \\
& Promosi & .209 & .103 & .190 \\
& Harga & .162 & .064 & .202 \\
& Kualitas Pelayanan & .636 & .111 & .593 \\
\hline
\end{tabular}

a. Dependent Variable: Kepuasan Konsumen

Tabel 3 menunjukkan persamaan regresi linear berganda penelitian ini adalah sebagai berikut: $Y=\mathbf{2 . 3 8 0}+\mathbf{0 , 2 0 9 X _ { 1 } +}$ $0,162 X_{2}+0,636 X_{3}$

Persamaan regresi linear berganda tersebut dapat diartikan sebagai berikut:

1) Jika variabel Promosi, Harga dan Kualitas pelayanan tidak mengalami perubahan, atau bernilai sama dengan nol, maka Kepuasan konsumen bernilai 2.380 satuan.

2) Jika variabel Promosi ditingkatkan sebesar 1 satuan, maka Kepuasan konsumen akan meningkat sebesar 0,209 satuan
3) Jika variabel Harga ditingkatkan sebesar 1 satuan, maka Kepuasan konsumen akan meningkat sebesar 0,162 satuan.

4) Jika Kualitas pelayanan ditingkatkan sebesar 1 satuan, maka akan diikuti dengan peningkatan Kepuasan Konsumen sebesar 0.636 satuan.

\section{Pengujan Hipotesis}

Uji t

Uji ini dilakukan bertujuan untuk melihat tingkat signifikasi masing-masing variabel bebas terhadap variabel terikat yang dapat dilihat pada tabel di bawah ini : 
Tabel 4. Hasil Uji t

\begin{tabular}{|ll|r|r|}
\hline \multicolumn{1}{|c|}{ Model } & \multicolumn{1}{c|}{ t } & \multicolumn{1}{c|}{ Sig. } \\
\hline $1 \quad$ (Constant) & 1.670 & .100 \\
& Promosi & 2.022 & .048 \\
& Harga & 2.536 & .014 \\
& Kualitas Pelayanan & 5.711 & .000 \\
\hline
\end{tabular}

Tabel 4 menunjukkan bahwa nilai signifikan dari variabel Promosi $\left(\mathrm{X}_{1}\right)$ adalah sebesar 0.048 lebih kecil jika dibandingkan dengan nilai alfa sebesar 0.050 dengan demikian dapat disimpulkan bahwa promosi berpengaruh signifikan terhadap Kepuasan konsumen. Selanjutnya pada variabel Harga $\left(\mathrm{X}_{2}\right)$ diketahui nilai signifikansi adalah sebesar 0,014 lebih kecil jika dibandingkan dengan niai alfa sebesar 0,050. Dengan demikian dapat disimpulkan bahwa Harga berpengaruh signifikan terhadap Kepuasan konsumen. Kemudian pada variabel Kualitas Pelayanan $\left(\mathrm{X}_{3}\right)$ diketahui nilai signifikansi adalah sebesar 0,000 lebih kecil jika dibandingkan dengan niai alfa sebesar 0,050. Dengan demikian dapat disimpulkan bahwa Kepuasan Konsumen berpengaruh signifikan terhadap Kepuasan konsumen

\section{Uji F}

Uji serempak dilakukan untuk melihat tingkat signifikansi ketiga variabel bebas secara bersama - sama berpengaruh terhadap variabel terikat. Hasil uji secara serempak dapat dilihat pada tabel dibawah ini:

Tabel 5. Hasi Uji F

ANOVA $^{b}$

\begin{tabular}{|l|r|r|r|r|r|}
\hline Model & Sum of Squares & df & Mean Square & F & \multicolumn{1}{c|}{ Sig. } \\
\hline Regression & 467.364 & 3 & 155.788 & 88.28 & $.000^{\mathrm{a}}$ \\
& 98.819 & 56 & 1.765 & & \\
Residual & 566.183 & 59 & & & \\
Total & & & & \\
\hline
\end{tabular}

a. Predictors: (Constant), Promosi, Harga, Kualitas Pelayanan

b. Dependent Variable: Kepuasan Konsumen

Tabel 5 menunjukkan bahwa nilai signifikansi adalah sebesar 0.000 lebih kecil dari nilai alfa sebesar 0.050, dengan demikian dapat disimpulkan bahwa Promosi, Harga dan Kualitas pelayanan secara bersama - sama berpengaruh terhadap Kepuasan konsumen.

\section{Koefisien Determinasi}

Untuk dapat mengetahui besarnya determinasi Harga dan Kualitas pelayanan menjelaskan Kepuasan konsumen dapat dilihat pada tabel berikut ini: 
Tabel 6. Koefisien Determinasi

\begin{tabular}{l|r|r|r|r|}
\hline Model & \multicolumn{1}{c|}{ Rodel Summary } \\
\hline 1 & R Square & $\begin{array}{c}\text { Adjusted R } \\
\text { Square }\end{array}$ & $\begin{array}{c}\text { Std. Error of the } \\
\text { Estimate }\end{array}$ \\
\hline
\end{tabular}
a. Predictors: (Constant), Kualitas Pelayanan, Harga, Promosi
b. Dependent Variable: Kepuasan Konsumen

Berdasarkan pada tabel 6 diketahui bahwa nilai R-Square adalah sebesar 0,825 atau sama dengan 82,6\%. Artinya bahwa Promosi, Harga dan Kualitas pelayanan mampu menjelaskan Kepuasan konsumen adalah sebesar $82,6 \%$ sisanya $17,4 \%$ dijelaskan oleh variabel lain yang tidak dimasukkan ke dalam model penelitian ini.

\section{SIMPULAN}

Berdasarkan pada penjelasan penjelasan sebelumnya maka Penelitian ini dapat disimpulkan sebagai berikut:

1. Terdapat pengaruh yang signifikan Promosi terhadap Kepuasan konsumen di PT Maxim Houseware Indonesia Medan. Besarnya pengaruh Promosi terhadap Kepuasan konsumen adalah sebesar $20,9 \%$

2. Terdapat pengaruh yang signifikan Harga terhadap Kepuasan konsumen di PT Maxim Houseware Indonesia Medan. Besarnya pengaruh Harga terhadap Kepuasan konsumen adalah sebesar $16,2 \%$.

3. Terdapat pengaruh yang signifikan Kualitas pelayanan terhadap Kepuasan konsumen di PT Maxim Houseware Indonesia Medan. Besarnya pengaruh Kualitas pelayanan terhadap Kepuasan konsumen adalah sebesar 63,6\%.

4. Promosi, Harga dan Kualitas pelayanan secara bersama - sama berpengaruh signifikan terhadap Kepuasan konsumen di PT Maxim Houseware Indonesia Medan, dengan tingkat kemampuan Promosi, Harga dan Kualitas pelayanan untuk menjelaskan Kepuasan konsumen adalah sebesar $82,5 \%$ sedangkan sisanya sebesar $17,5 \%$ dijelaskan oleh variabel lain yang tidak dimasukkan ke dalam model penelitian ini.

\section{Saran}

Berdasarkan pada kesimpulan tersebut diatas, maka saran - saran perlu untuk diberikan sebagai berikut :

1. Untuk dapat meningkatkan Kepuasan konsumen di PT Maxim Houseware Indonesia Medan, pimpinan perusahaan harus sedapat mungkin untuk memperhatikan Promosi, Harga dan Kualitas pelayanan karyawan.

2. Manajemen perusahaan sebaiknya lebih meningkatkan promosi dengan cara yang berbeda, diluar seperti yang telah dijelaskan sebelumnya. Beberapa promosi yang dilakukan seperti melakukan event dengan programprogram khusus yang menyebabkan konsumen lebih mudah untuk memiliki produk perusahaan, tanpa harus susah dan mengeluarkan uang lebih banyak. Program-program dimaksud seperti program akhir tahun dengan memberikan diskon kepada produk-produk yang sudah terlalu lama tersimpan di gudang, perusahaan juga dapat membuat program lain yang sejenis

3. Harga merupakan variabel yang paling besar mempengaruhi Kepuasan konsumen. Ini artinya bahwa harga merupakan hal yang paling disukai oleh harga untuk meningkatkan Kepuasan konsumennya. Pimpinan perusahaan harus dapat menawarkan harga kepada konsumen yang sesuai dengan kemampuan konsumen. 
4. Sebaiknya bagi peneliti yang akan datang dapat melakukan penelitian dengan menambahkan variabel - variabel lain yang lebih besar pengaruhnya terhadap Kepuasan konsumen.

\section{REFERENSI}

Alma, Buchari, (2004), Manajemen Pemasaran dan Pemasaran Jasa, Penerbit Alfabeta, Bandung.

Atmaja, A.K. 2011. Analisis pengaruh Kualitas Pelayanan Terhadap Kepuasan Pelanggan (Studi pada Tiket Garuda di PT. Falah Fantastic Tour Travel Bogor). Skripsi, Ekonomi-S1, Fakultas Ekonomi, Universitas Diponogoro, Semarang.

Deli Putra, Naimuddin (2000), Karakteristik Pelayanan, Penerbit PT. Gramedia Pustaka Utama. Jakarta.

Fitzsimmons, (2001), Pelayanan Barang dan Jasa, Terjemahan Alih Bahasa Ellen Gunawan Sitompul, Uka Wikarya, dan Anton Hendranata Penerbit Kanisius, Yogyakarta.

John C Mowen dan Michael Minor, 2002, Perilaku Konsumen, Binarupa Aksara,Jakarta.

Khatimah, Husnul. 2011. Analisis Pengaruh Kualitas Pelayanan Terhadap Kepuasan Nasabah (Studi pada Nasabah BRI Cabang Semarang Pattimura). Skripsi, Ekonomi-S1, Fakultas Ekonomi, Universitas Diponogoro, Semarang

Kotler, Philip, (2001). Manajemen Pemasaran di Indonesia, Buku I, Jakarta, Penerbit Salemba Empat.

Lupiyoadi Rambat, (2001), Menajemen Jasa, Teori dan Praktik, Edisi pertama, Penerbit Salemba Empat, Jakarta.

Rangkuti, Freddy (2002), Riset Pemasaran, Penerbit Elex Media Computindo, Jakarta
Swasta Basu, 2001, Konsep dan Strategi Analisa Kuantitatif Saluran Pemasaran, Edisi Ketiga, Yogyakarta, BPFE-UGM.

Sugiarto, Endar, (2002), Psikologi Pelayanan Dalam Industri Jasa, Penerbit PT. Gramedia Pustaka Utama, Jakarta.

Sunarto (2003), Perilaku Konsumen, Yogyakarta, Penerbit AMUS dan CV dan Ngeksigndo Utama

Tjiptono, Fandy, (2005), Pemasaran Jasa. Edisi Pertama, Malang, Bayu Media

Yoeti, Oka A., (2001), Strategi Pemasaran Jasa, Penerbit Gramedia Pustaka Utama, Jakarta.

Payne, Adrian, (2000), Pemasaran Jasa, Cetakan I, Edisi I, Penerbit Andi offset, Yogyakarta.

www.suyatno.blog.undip.ac.id 